\title{
A Hyper-Royalist Parapolitics in Thailand
}

\author{
Tyrell Haberkorn* \\ Department of Political and Social Change, Australian National University \\ tyrell.haberkorn@anu.edu.au
}

\begin{abstract}
In the years since the 19 September 2006 coup, there has been a resurgence in prosecutions under Article 112 of the Thai Criminal Code, the measure which criminalizes and provides for harsh penalties for alleged lèse majesté. One of the striking features of recent court decisions in Article 112 cases is that judges have gone beyond the boundaries of law to justify the convictions, and developed a jurisprudence that centres on monarchical heritage. Right-wing citizens have taken similar ideas as a justification to engage in violence against those with whom they disagree. This article develops a framework - hyper-royalist parapolitics - to examine an attack on law activists, a Criminal Court decision, and a Constitutional Court comment which represent this new political form, and to query the broader transformations they signal in the Thai polity. The article concludes with reflections on the framework in light of the 22 May 2014 coup.
\end{abstract}

\section{Keywords}

Thailand - monarchy - parapolitics - royalism - lèse majesté - freedom of expression human rights

The 19 September 2006 coup that ousted elected prime minister Thaksin Shinawatra set in motion a cycle of fractious contention, open disagreement, and,

* The research for this article was supported by an Australian Research Council Discovery Early Career Researcher Grant (DE120101838) on 'Impunity and Human Rights in Thailand'. I would like to thank the organizers of the 'Performing the State' project, Jeremy Kingsley and Kari Telle, as well as the two anonymous reviewers for their suggestions for revision.

(C) TYRELL HABERKORN, 2016 | DOI: 10.1163/22134379-17202003

This is an open access article distributed under the terms of the Creative Commons Attribution-Noncommercial 3.o Unported (CC-BY-NC 3.0) License. 
at times, devastating violence in Thailand. ${ }^{1}$ The most visible aspect of this was the colour-coded protest politics of the broadly populist-democratic red shirts and the broadly conservative-royalist yellow shirts. One of the primary questions at the centre of the protests and counter-protests was what form rule would take in the Thai polity, who could participate in politics, and what forms of participation would be permitted. In March 2010, thousands of red-shirt protestors entered Bangkok for extended protests and called for the resignation of then prime minister Abhisit Vejjajiva, who had been appointed rather than elected, and for elections. In April-May 2010, clashes between red shirts and Thai state forces rapidly became a crackdown by the latter against the former and resulted in 94 deaths and over 2,00o injuries, the majority borne by civilians (People's Information Centre 2555 [2012]). ${ }^{2}$ Elections were finally held in July 2011, and Yinguck Shinawatra, the leader of the red-shirt-aligned Pheu Thai Party and Thaksin's younger sister, was elected. In late 2013, a series of protests by a yellow-shirt-aligned royalist coalition, People's Democratic Reform Committee (PDRC), calling for the removal of the Pheu Thai Party government again raised the spectre of possible violence and fragmentation in the polity. ${ }^{3}$

Although the immediate prompt for the protests was an ill-advised push by the Pheu Thai Party to pass an amnesty bill that would have paved the way for Thaksin's return to the country, the PDRC or a similar group would have soon emerged within the fractious political context. In response to the protests, then prime minister Yingluck Shinawatra dissolved parliament and elections were set for February 2014. The PDRC boycotted the elections and ensured that in many districts candidates could not register to run, and that, on election day, many voters could not reach the polls to vote. In March and April 2014, the PDRC continued to protest as the caretaker Pheu Thai Party government was increasingly attacked and became less and less able to govern. This is the context in which a junta calling itself the National Council for Peace and Order, (NCPO), led by General Prayuth Chan-ocha, then commander-in-chief of the Royal Thai Army, launched a coup and seized power on 22 May 2014. At the

1 For an analysis of the coup and the events leading up to it in English, see Connors and Hewison 2008; for an analysis in Thai, see Thanapol 2550 [2007].

2 Citations for Thai-language sources give the Buddhist Era date first and then the Common Era date enclosed in suqare brackets. See Tausig 2013 and Sopranzetti 2013 for accounts of the red-shirt movement leading up to and during the 2010 protests. See Montesano, Aekapol and Pavin 2012 for a collection of articles about the April-May 2010 protests and their aftermath.

3 The translation of the Thai name of the PDRC is actually People's Committee for Absolute Democracy with the King as Head of State, but they use the name People's Democratic Reform Committee in English. 
time of writing (early 2016), it is both clear that the NCPO is the most repressive regime since that of Prime Minister Thanin Kraivichien (1976-1977) in terms of violations of human rights, and that the junta's timeline for their exit from power is unclear. At present, and for the foreseeable future, only soldiers and those approved by them will participate in the rule of the polity.

Simultaneously with the emergence of colour-coded politics amidst the two recent coups, there has been a growing crisis about the monarchy's place within the polity (Marshall 2014; Ünaldi 2016). The current monarch, Bhumibol Adulyadej, is tremendously powerful symbolically, politically, and economically (Gray 1986; Ivarsson and Isager 2010). However, Bhumibol is 88 and in poor health, having been hospitalized for much of the time since September 2009. Bhumibol's son, Vajiralongkorn, the crown prince, is officially next in line for the throne, but even staunch royalists are not as enthusiastic about him as they are about his father. Despite their misgivings, a smooth transition is desired by the institution of the monarchy as well as the military, capital, and other elites who benefit from their connections to it, who comprise what Duncan McCargo (2005) calls the 'network monarchy'. The combination of the political contention and instability of the last ten years, the questions of participation and rule which animate it, and the anxiety surrounding succession mean that the place of the monarchy within the polity has become uncertain. The sharpest indication of this is the dramatic upsurge since the 2006 coup, and the further intensification since the 2014 coup, in the use of Article 112, the legal measure that defines and stipulates punishment for the crime of lèse majesté: 'Whoever defames, insults or threatens the King, the Queen, the Heir Apparent or the Regent, shall be punished with imprisonment of three to fifteen years.' ${ }^{4}$ Although Article 112 has been part of the Criminal Code since its last revision in 1957 , and the penalty was increased following the 6 October 1976 coup, its

4 Neither the Office of the Judiciary nor the police release complete information about the number of complaints filed under Article 112 or the outcome of those complaints. However, the combination of information and that compiled by human-rights activists creates a partial picture. Illustrating the rise following the 19 September 2006 coup, the number of complaints filed under Article 112 rose from 33 in 2005, to 30 filed in 2006, 126 filed in 2007, 77 filed in 2008, 164 filed in 2009, and 478 filed in 2010; see “"Thaeng upalak": Sadaeng sathit khadi min klang thanon ratchadamnoen', 2554 [2011], Prachatai, 17-12-2011, http://prachatai .com/journal/2011/12/38371 (accessed 20-3-2013). The Internet Dialogue on Law Reform, or iLaw, a Thai governmental organization, has documented at least 62 new cases of alleged violation of Article 112 that have entered the court system between the 22 May 2014 coup and the end of 2015. See the iLaw website (http://www.ilaw.or.th) for case statistics updated monthly. 
current usage far exceeds earlier known uses (Streckfuss 2011). Any individual can file a complaint of alleged violation of Article 112, and the increase in usage has resulted from complaints filed by both state officials and private citizens. Once a complaint is filed, the police are compelled to investigate and make a decision about whether or not to forward the complaint to the prosecutor, who then must make a decision about whether or not to take the case to court. Police and prosecutors are often either similarly zealous or too afraid to potentially appear disloyal to the monarchy to dismiss complaints brought under the law. The combination of these factors leaves the law open for both state officials and private citizens to use it to harass or exact revenge upon one's personal enemies. Yet concomitant with the use of the law, actions beyond, or at least outside, the purview and control of the law have emerged as well. These actions in excess of the law, which I identify as hyper-royalist parapolitics, are the primary topic in the remainder of this article.

In calling these actions 'hyper-royalist', I draw on Thongchai Winichakul's conception of hyper-royalism, which he notes has come to dominate Thai political and social life in the years since the 19 September 2006 coup. While explicit state promotion of the monarchy has been routine since the regime of Field Marshal Sarit Thanarat (1958-1963), its extent, forms, and effects have greatly intensified in recent years to become a grave threat to democracy and the rule of law (Thak 1979:181-222). The currently dominant form of hyper-royalism has five primary characteristics. First, royalism has come to be a part of the daily life of many people. Space and time in people's lives have increasingly come to be filled with activities about or surrounding the monarchy. This includes, for example, the proliferation of television shows tracking the good deeds, travels, and personal details of members of the royal family. Second, the king and the court have been elevated to be higher than other human beings, in a fashion neither necessary nor appropriate nor flattering. Third, the monarchy has become a sacred entity and the relationship between the people and the monarchy has come to be governed by belief. Fourth, a combination of laws and social measures compels citizens to display complete respect for the monarchy, in recognizable, nearly identical ways. Fifth, hyper-royalism is not only a product of the state: the religiosity of the ideas about the monarchy have been largely produced and consolidated through social processes, including rampant commodification and consumption (Thongchai 2012). Hyper-royalism's connection with the sacred has caused the monarchy and those associated with it to become dangerously unquestionable.

As new para-state groups have emerged and old groups have reconsolidated in defence of the monarchy, a focus on parapolitics, which 'uses the varying levels of interaction between conventional states and quasi-statist entities as 
the basis for formulating an analytic perspective that privileges neither the state nor its alternatives' makes it possible to comprehend and analyse within the same frame the disparate moments in which hyper-royalism becomes the basis for official state policy or vigilante action (Wilson 2009:30). Writing about the genealogy of the study of parapolitics, Robert Cribb (2009:1) notes that at its core is the idea 'that clandestine activity by state institutions and by institutions linked to the ruling elite played a major role in sustaining illiberal and anti-democratic features of the system'. Criminals behave as sovereigns and sovereigns behave as criminals. Cribb (2009:8) argues that parapolitics is not simply what one studies when one examines this reversal of behaviour, but that parapolitics is itself the evident insight. With hyper-royalist parapolitics, the constructed sacredness of the monarchy provides an additional dimension of potential illiberal and anti-democratic effects of the parapolitical. The zeal for the sacredness of the Thai monarchy may contribute directly to violence and violation of rights, while simultaneously making redress both impossible and profane.

By examining instances of hyper-royalist 'parapolitics', my goal is to signal the forms and mechanisms through which hyper-royalism blurs the boundaries between the state and the para-state, which includes both organized citizen groups and individuals who take on the vigilante-style protection of the monarchy. Such muddying of the waters leads to further blurring of the lines between the extrajudicial and the legal, and in so doing, connects to violence. The way in which I approach the Thai state is informed by Craig Reynolds (2012: 2), who argues that it should be viewed, 'not as an institution but as an entangled mess of interlocking relationships, alliances, and struggles between and among many centres of power often in competition with one another'. This critical lens on the actions of state entities and officials resonates with what Christopher Krupa and David Nugent (2015:5) argue in their work on Andean states, which is 'to view states both as off-centred political fields and from offcentred locations of analysis' (italics in original). To examine hyper-royalism as it crosses the blurry line between the state and the para-state is to acknowledge that the Thai state is an off-centred political field. To do so not from the perspective of the state, but from that of the citizens who suffer at their hands, is an off-centred analytic location.

In the remainder of this article, I further elaborate the particular mechanisms and dangers of hyper-royalist parapolitics by examining in depth two instances from 2012, thus from the latter part of the inter-coup years (20062014), a period which in retrospect held a tremendous possibility of progressive democratic social change as well as rising hyper-royalism. The first, from January 2012, is a series of online threats to progressive law lecturers. The second, 
from October 2012, is a Constitutional Court comment issued during the adjudication of an Article 112 case. In both of these cases, vigilantism, or the presence of a self-appointed arbiter for the protection of the monarchy, and therefore the nation, is evident. Similar to Atreyee Sen's and David Pratten's (2008) warning that vigilantism is on the rise, these two cases heralded a concerning turn within the Thai polity. Yet the vigilantism Sen and Pratten trace is one, they argue, that has morphed in various locations in response to globalization and neo-liberalism. What I examine here is instead how an inward-looking vigilantism emerges at a time of uncontained national crisis. In the service of protecting the monarchy, every loyal citizen and civil servant can choose to perform as the sovereign. Ordinary citizens call for dissident citizens to be cast out of the polity. Eager judges reinterpret the constitution to protect only the monarchy, not the citizens named within it as subjects.

In these two instances of hyper-royalist parapolitics, the state and para-state and the law and extra-judicial violence intersect with one another in different ways. Hyper-royalist parapolitics are not accidental or limited to one area of society, nor are the protagonists limited to one category of citizens or section of society. These two examples of hyper-royalist parapolitics, which span only nine months, offer a snapshot of the late inter-coup years in Thailand, as well as the crisis of sovereignty that pervaded social and political life within it. I conclude by reflecting on the intensification of this crisis following the 22 May 2014 coup.

\section{Online Vigilantes}

The difference between a successful and an unsuccessful coup is the difference between ascending to power and potentially being charged with treason. This distinction was not lost on the Council for Democratic Reform under the Constitutional Monarchy (CDRM), the junta that launched the 19 September 2006 coup that ousted former prime minister Thaksin Shinawatra. They took a series of legislative measures to ensure that they were protected. When the CDRM launched the coup, one of their first actions was to nullify the 1997 Constitution. They then released a new, interim constitution comprised of thirty-nine sections, including two that ensured the protection of the CDRM from criminal prosecution for their actions. Section 36 legalized all of the junta's prior statements, and Section 37 provided immunity for the junta's actions in launching the coup. The Constitutional Drafting Assembly, appointed by the CDRM, did not include provisions in the 2007 Constitution that affected these two sections of the interim Constitution. 
Instead, five years after the coup, opposition and a trenchant critique came from the Khana Nitirat (Enlightened Jurists), a group of seven progressive law lecturers at Thammasat University led by Professor Worachet Pakeerut. The Khana Nitirat, whose name is inspired by the Khana Ratsadorn, or People's Party, the group who fomented the transformation from absolute to constitutional monarchy on 24 June 1932, was established on 19 September 2010, the fourth anniversary of the coup. Until the 22 May 2014 coup, they held regular seminars open to the public and issued statements and analyses of current political developments that made law accessible to the people. ${ }^{5}$ As an activist legal-academic group, the Khana Nitirat has antecedents in both long-standing progressive activism by intellectuals and cause lawyering in Thailand (Munger 2011, 2012).

One of the characteristics of post-September 2006 coup politics in Thailand has been the rapid judicialization of politics, or the increased use of the courts as the location for debates and decisions on politics and related social and moral issues (Dressel 2010, 2012). The increased use of judicialization as a political tool of the elite in Thailand has necessitated the development of a sophisticated repertoire of legal knowledge by dissident critics. What made the Khana Nitirat's activism important and unique is that they did not only critique judicialization themselves, but also provided the tools for critique to all those who read their statements and attended their seminars.

In the statement the Khana Nitirat issued on the fifth anniversary of the 2006 coup, they took up Sections 36 and 37 of the temporary constitution. They began by noting that ' $[t]$ he 19 September 2006 coup was an illegal act. The coup destroyed the rule of law and democracy. The coup remains the primary cause of political conflict from then until the present.' ${ }^{6}$ The Khana Nitirat's response to the problems caused by the coup and the series of legal measures that went along with it was to suggest that the coup and its resultant effects be nullified. In particular, they called for Sections 36 and 37 of the 2006 interim constitution to be declared null and void and the investigations of various courts and the Assets Scrutiny Committee, which was tasked by the CDRM with examining

5 See the Khana Nitirat website for an archive of their statements and other publications: http:// www.enlightened-jurists.com (accessed 19-1-2016). The majority of the documents are only available in Thai, but key documents are available in English and French translation. See McCargo and Peeradej (2015) for an analysis of the genesis and movement of the Khana Nitirat.

6 All translations in this article are my own. Khana Nitirat, "Thalaengkan Khana Nitirat Nuang Nai Okat Khroprop 1 Pi Nitirat', 2554 [2011], http://www.enlightened-jurists.com/blog/44 (accessed 20-1-2016). 
the assets of all of the ministers in former prime minister Thaksin Shinawatra's government to be declared void. In this proposal, the goal of the Khana Nitirat was not to pave the way for the return of Thaksin Shinawatra, as some critics charged, but rather to create the space for the return of the rule of law. On the issue of accountability for wrongdoing during the Thaksin government, they noted that their suggestions

do not constitute an amnesty or a pardon or an absolving of those individuals accused of wrongdoing. This is not an expunging of all of the actions of those individuals accused of wrongdoing. Therefore, new cases can be started against those relevant individuals in accordance with the standard legal process. ${ }^{7}$

In the remainder of the statement, the Khana Nitirat called for a review of Article 112, guaranteed protection of the rights of all political detainees and prisoners, and for a new constitution to be drafted and promulgated in a participatory manner.

The statement was greeted with harsh criticism from some segments of the armed forces and the opposition Democrat Party. In particular, General Prayuth Chan-ocha, then already commander-in-chief of the Royal Thai Army and future leader of the 22 May 2014 coup, commented that the Khana Nitirat must be careful not to cause divisions in society. Sakonthi Phattiyakul, the deputy spokesman for the Democrat Party, accused the Khana Nitirat of trying to confuse the people and of acting in its own self-interest in the hope of being appointed to a new constitution drafting committee. ${ }^{8}$ In this criticism, one can both hear a denial of the plurality of views in society and an attempt to cynically foreclose the possibility that members of civil society might take action in the service of the broader good. Sakonthi's accusation that the Khana Nitirat was acting out of self-interest reflects his own failure to imagine that one might offer comment and criticism of how rule takes place and who is excluded from it in order to improve it, rather than use it as a ploy to seek power oneself. But after an initial burst of criticism, the massive floods which devastated Bangkok in late 2011 put an end to the criticism and also put the Khana Nitirat's campaign on hold.

7 Khana Nitirat, 'Thalaengkan Khana Nitirat Nuang Nai Okat Khroprop 1 Pi Nitirat', 2554 [2011], http://www.enlightened-jurists.com/blog/44 (accessed 20-1-2016).

8 Bangkok Post, 27-11-2011. 
After the new year, the Khana Nitirat resumed their intellectual-political activities in full. On 15 January 2012, along with the Khana Ronarong Kaekhai Matra 112 (Campaign Committee to Amend Article 112, CCAA 112), the Khana Nitirat publicly launched a campaign for the amendment of the section of the Criminal Code describing and criminalizing alleged lèse majesté. The proposal to amend Article 112 included the following provisions: (1) Categorize the crime of lèse majesté as a crime of defamation and dishonour rather than one of violating national security; (2) Differentiate crimes defaming, insulting and threatening the King, Queen, Heir Apparent and Regent, rather than leaving them grouped together; (3) Make the punishment more proportionate, by not mandating a minimum punishment, reducing the punishment for actions defaming, insulting and threatening the King to a maximum of 3 years or a fine of 50,00o baht, and actions defaming, insulting and threatening the Queen, Heir Apparent, or Regent to a maximum of 2 years or a fine of 30,000 baht; (4) To decriminalize and permit criticism and statements made in good faith for the public interest or in the service of knowledge about the monarchy; and (5) For the power to accuse and file a complaint to be transferred solely to the Office of His Majesty's Principal Private Secretary, rather than any private citizen. ${ }^{9}$

One week after launching the campaign to amend Article 112, the Khana Nitirat held a public seminar to again raise their proposal to nullify the 2006 coup. This time, the residents of Bangkok were not preoccupied with impending floods. The response reflected the challenge the Khana Nitirat posed to the legitimacy of the coup, the administrations that have followed it, and the broader intersection of the monarchy, military, and politics.

The day after the Khana Nitirat presented their proposal, an article about the seminar posted on the online version of the pro-coup and royalist Phuchatkan (Manager) newspaper, garnered hundreds of reader comments. While the politicization of social media and online social sanctioning has become particularly common in Thailand, in this case, there was a starkly vicious slant to it. The comments were full of unconstructive misreadings of the Khana Nitirat proposal, but more than that, they contained a virulent thread of hatred. Within the first twenty-four hours, 227 comments were posted. While several commenters took the proposal of the Khana Nitirat seriously, many com-

9 Under the 2007 Constitution, the parliament is obliged to examine any proposed amendment to law that receives support from at least 10,00o citizens. Following the launch of the campaign in Bangkok in January 2012, the CCAA 112 organized seminars and events around the country to explain the proposed amendment to the law and collect signatures in support of it. On 28 May 2012, the CCAA 112 submitted the proposed amendment and signatures from 30,838 citizens. Parliament refused to examine the proposal. 
menters chose to forego engagement and instead threatened the members of the Khana Nitirat. Many comments suggested that the members of the Khana Nitirat were not Thai and should leave the country. Others described the members of the Khana Nitirat as less than human, and described them as dogs and aliens. Some commenters called for a direct response from the military, including the suggestion of a coup, querying the pride of the army, and asking why soldiers were not doing anything about the proposal. In normal times, to call for a coup in response to a proposal with which one disagrees would seem to be extreme. Here, the fact that in comparison to other comments this is an almost mild reaction reveals the presence of a sharp polarization in Thai society.

Other commenters called for the Khana Nitirat to be watched carefully, and specifically asked for the names, addresses, phone numbers, and maps of the house locations of the members of the Khana Nitirat to be published, and for everyone reading the comments to be the eyes and ears, that is, to be an informal surveillance network. It is likely that members of the official intelligence services, including the Special Branch police and various military intelligence agencies were surveilling the Khana Nitirat, or perhaps attending the seminars and photographing the speakers as well as the audience. Members of intelligence agencies are a feature of political events in Thailand and tend to be easily spotted due to their attire of conspicuously casual clothing. While they are not in uniform, their pressed jeans, well-shined shoes, and late-model digital cameras set them apart from the other attendees, even if they are also wearing jeans and taking photographs. Either members of the intelligence agencies lack the observational skills to notice how different they appear from those around them, or this difference is intentional and they aim to intimidate those around them by making their presence known. What they do with the photographs they take and information they collect remains unknown; the purpose of their presence seems to be as much intimidation as it is intelligence-gathering. The call for citizen-surveillors on the Phuchatkan website, on the other hand, is more ominous, primarily because they would be even less accountable than the state intelligence agencies.

What was most striking about the comments, however, was that in some the authors called for violence to be committed against the members of the Khana Nitirat. These included that soldiers should make the members of the Khana Nitirat disappear by throwing them from helicopters; the members of the Khana Nitirat and their families should be necklaced and burned alive in front of their houses; and the members of the Khana Nitirat should be beheaded and their heads put on stakes outside the front of the entrance to Thammasat University. Over the next week, hundreds more comments were 
posted, many with the real names and email addresses of the authors noted, even when the content advocated violence or other criminal actions. ${ }^{10}$

The people who posted the comments were not organized in a formal organization that might be characterized as a para-state entity, but their actions were clearly parapolitical. This is the case even though it is impossible to know if, and how, the online comments were linked to actions taken offline. In the accusation that the members of the Khana Nitirat were not Thai and the calls for their murder, the criminals or would-be criminals acted as sovereigns poised to decide who was or was not a member of the polity, and who would be murdered and who would be spared. The comments posted online were part of the creation of an atmosphere in which dissent and difference were not tolerated, and questioning the role of the monarchy in politics was equated with dangerous disloyalty. Perhaps what is most telling is that no action was taken against those individuals who posted detailed death threats. This is particularly shocking when considering the extensive state resources which have been devoted to tracking down the authors of anonymous comments deemed to insult or defame the monarchy. Here, the effect of hyper-royalism is evident in the lack of concern with which the threats against the Khana Nitirat were received, either by the publishers of Phuchatkan or Thai state entities.

At the end of February 2012, the leader of the Khana Nitirat, Professor Worachet, was attacked outside his office at the Faculty of Law at Thammasat University by a pair of male twins. When they made a statement to the police, they asserted that the reason that they attacked him was because they disagreed with Professor Worachet's ideas; the twins were charged and prosecuted for assault."1 Like the people who commented on the Phuchatkan webboard, the twins did not identify themselves as members of any particular group or organization.

This suggests that hyper-royalism is potent enough to empower individuals to take action on their own. In late 2012, in an article for Matichon newspaper, historian Nidhi Eoseewong identified elements of totalitarianism in Thailand. Drawing on Hannah Arendt's The origins of totalitarianism, he cautioned read-

10 The comments are no longer archived online as of 2016, but many of them are included in an earlier version of the analysis in this section that I wrote in Elizabeth Fitzgerald, 'A catalogue of threats against the Khana Nitirat', New Mandala, 24-1-2012, http://asiapacific .anu.edu.au/newmandala/2012/01/24/a-catalogue-of-threats-against-the-khana-nitirat/ (accessed 20-1-2016).

11 Asian Human Rights Commission, 'THAILAnd: Threats to political freedom intensify with assault on HRD and law professor', 4-3-2012, http://www.humanrights.asia/news/ahrc -news/AHRC-STM-040-2012 (accessed 20-1-2016). 
ers to be aware of growing atomization in Thai society. ${ }^{12}$ As individuals feel less connected with one another, the possibility of building a democratic culture diminishes. Simultaneously, the possibility for individual vigilante action increases. The assault on Professor Worachet was an illustration of this phenomenon.

For those who wish to join with others to engage in hyper-royalist vigilantism, the increased use of Article 112 prompted the emergence of new organizations dedicated to the protection of the monarchy. To name only a few, in 2010 the Special Branch police called for citizen volunteers to monitor online content and report anti-monarchy content to them. In 2011, a group of young people calling themselves Rak Pho Phak Patipat (Loving Action for Father) went through Bangkok removing anti-monarchy graffiti and made a documentary video of themselves doing so. ${ }^{13}$ In 2014, physician and former naval officer Rienthong Naenna called for the members of a new group for citizen-surveillors, the Ongkan Kep Khaya Phaendin (Organization to Collect the Nation's Trash), to observe their neighbours and collect information about those who allegedly insulted or defamed the monarchy in order to file police complaints against them. Following the 22 May 2014 coup, Rienthong and his fellow citizen-surveillors remain active.

\section{A Vigilante Judiciary}

The second example of hyper-royalist parapolitics emanates from a state entity: the judiciary. Similar to the commenters on the Phuchatkan website examined above, the behaviour of both the Constitutional and the Criminal Court in the prosecution of Somyot Prueksakasemsuk, a noted labour rights activist and human-rights defender, under Article 112 is both hyper-royalist and parapolitical. The courts have gone beyond the action of protecting the monarchy to attempt to cast the institution as timeless, beyond question, and sacred. When a citizen does this, it raises a question about the presence of extremism in society. When it is done by a state entity whose roles are to determine and enforce the laws of the land and to protect the constitution and the citizens who live under it, then it signals a substantial crisis in the polity.

12 Nidhi Eoseewong, 2555 [2012], 'Phadetkan betset', Matichon Weekly, 23-29 November, pp. $30-32$.

13 The short documentary can be viewed here: YouTube, http://www.youtube.com/watch ?feature=player_embedded\&v=zpP5aWSflpo (accessed 26-1-2016). 
In the aftermath of the April-May 2010 violence in Bangkok, on 24 May 2010, Somyot Prueksakasemsuk was arrested and detained for nineteen days by the Centre for the Resolution of the Emergency Situation (CRES), the agency empowered to deal with the political and social unrest arising from the redshirt protests. Under the Emergency Decree, which was in place at the time, arbitrary detention without charge for up to thirty days was permitted. Somyot was released after nineteen days of detention with no explanation.

Then, on 30 April 2011, Somyot was arrested again and subsequently charged with violating Article 112. He was charged in relation to two articles that were published in Voice of Taksin magazine, a print publication that he worked with as a key member of the editorial team. The reason why I say he was charged in relation to the two articles is that he was not the author of the two articles found to be egregious by the prosecutor. The two articles, published under the pseudonym Jit Phonlachan, were written by Jakrapop Penkair, the former spokesperson of Prime Minister Thaksin Shinawatra's government. At the time that Somyot was arrested, Jakrapob was living in exile in Cambodia.

During the long period of pretrial preparations and the trial, despite numerous requests for bail, Somyot was never granted release. Bail is routinely denied in Article 112 cases. The court cites the classification of the crime as one of national security and the potentially lengthy sentence, and therefore the possibility of flight by the defendant, as the reason for the denial.

The Criminal Court decision was originally scheduled to be read on 19 December 2012, but it was delayed due to the reading of a comment by the Constitutional Court. The Constitutional Court was established by the 1997 Constitution, and it was retained in the post-coup 2007 Constitution. The Constitutional Court is comprised of nine judges suggested by the Senate and appointed by the king. These nine judges include three judges from the Supreme Court, two judges from the Supreme Administrative Court, two experts in political science and two experts in law. The Constitutional Court does not hold open sessions, but rather offers comments and rules on a range of petitions submitted by different parties. One of the key differences between the roles of the Constitutional Court under the two constitutions is that in the 2007 version, the Constitutional Court examines petitions from individual citizens alleging a violation of rights and determines whether or not a specific legal provision is constitutional (Harding and Leyland 2011:165). The court holds 'final authority over all matters of constitutional interpretation' (Harding and Leyland 2011:164).

The comment, dated 10 October 2012, addressed a petition submitted by Somyot as well as a petition submitted by Ekachai Hongkangwan, who was prosecuted in a separate case for alleged violations of Article 112 stemming from selling CDs that contained copies of Wikileaks documents and a copy of an ABC 
(Australia) news programme critical of the Thai royal family. If the Constitutional Court accepts the petition of a person currently being prosecuted, the operations of the Criminal Court are placed on hold while the petition is examined. The comment addressed whether or not Article 112 was in contravention to three provisions of the constitution which protect the rights and liberties of the people. The Constitutional Court's response was unequivocal and concluded that Article 112 in no way contravened the constitution.

While the avenue of petition taken up by Somyot and Ekachai is one meant to offer individual citizens a method by which to protect their rights, in this instance the Constitutional Court acted in a fashion antithetical to this. There was a fundamental tension contained within the constitution that makes this possible. Section 2 reads, 'Thailand adopts a democratic regime of government with the King as Head of State.' Then, immediately following, Section 3 reads

The sovereign power belongs to the Thai people. The king as head of state shall exercise such power through the national assembly, the council of ministers and the courts in accordance with the provisions of this constitution. The performance of duties of the National Assembly, the Council of Ministers, the courts, the constitutional organizations and state agencies shall be in accordance with the rule of laws.

According to the constitution, sovereignty, then, belongs to both the people and the king. While there may be a context in which this could function democratically, present-day Thailand is not one of them. The reason is that the constitution does not go further to stipulate how sovereignty continues to belong to the people when a figure who is above criticism exercises it on their behalf. For Section 3 to be a democratic measure would, at a minimum, require that it be possible to question the relationship of the monarchy to politics or the involvement of the king in regime change, for example, without risking a prison term. Although the text of Article 112 prohibits defamation, insult, and threat, not criticism, judges do not always distinguish criticism from the actions covered by the law. What makes the Constitutional Court's actions here hyper-royalist is that they have not acknowledged the tensions as written in the constitution, but instead have only acted to defend the position of the king. By placing the monarchy above the people, the court goes beyond the constitution and acts parapolitically. This is not an example of either the sovereign acting like a criminal or a criminal acting like a sovereign, as per Robert Cribb's definition of parapolitics. What is not mentioned in his definition is the effect of parapolitics on the people, who are stripped of protection and suffer in both 
situations of reversal. In this case, the result is the same because the judiciary acts only in the service of the sovereign, and forsakes its responsibility to the people. While the commenters on the Phuchatkan website extrajudicially threatened the rights of citizens, here the Constitutional Court has provided the legal basis for their official violation.

The Constitutional Court framed their comment by citing Sections 2 and 8 of the constitution. Section 8 elaborates Section 2 and states that " $\mathrm{t}$ ] $\mathrm{he}$ King shall be enthroned in a position of revered worship and shall not be violated. No person shall expose the King to any sort of accusation or action.' Next, the Constitutional Court placed the present-day king within a long, unbroken lineage dating to the thirteenth-century Sukhothai kingdom $(1238-1438 \mathrm{CE})$. The court then noted that Thailand has had a king as head of state 'for a long time, since the Sukhothai era, even though there was a transformation in 1932 to a democratic regime with the king as head of the state under a constitution'. The transformation from absolute to constitutional monarchy on 24 June 1932 and the emergence of a new, more democratic regime is understood by the court to leave the place of the monarchy in the polity unchanged. The court continued, noting that ' $[\mathrm{u}] \mathrm{p}$ until the current constitution of the kingdom, the form of regime remains one with the king as head of the state' (Constitutional Court of Thailand 2555 [2012]:3). The court then commented on what this means, offering the interpretation that

[ $\mathrm{t}$ ]his demonstrates the great respect, esteem, and admiration held by the people for the institution of the monarchy. The place of the Thai king as the respected and beloved centre of the Thai people has been continuous, as shown in age-old royal traditions and legal conventions. The king has administered with virtue and taken action with the intention of the wellbeing of the people. In particular, King Bhumibol Adulyadej, the current monarch, greatly contributes to the nation and gives royal grace to the Thai people. He visits the people and bestows royally conceived projects on different areas in order to alleviate the suffering and solve the problems and troubles of the people. He teaches the people to subsist in line with the principles of the sufficiency economy, by living in line with the middle way, having enough, and being prepared to face changes which may arise. Ordinary people are aware of the king's conduct and his generosity. They therefore have deep-seated respect, trust, and loyalty for the king and the institution of the monarchy. The long-standing patronage of the Thai king has made the Thai people to continually respect, love, and admire the king. This is a unique characteristic of Thailand held by no other country (Constitutional Court of Thailand 2555 [2012]:4-5). 
For this reason, the Constitutional Court explained that the state provides protection because the king is the head of state and a primary institution of the country. The subtext of the claim to uniqueness is that the protections which rest on universal ideals of human rights do not apply. The court then noted that Article 112 is a complementary provision to Section 8 of the constitution (Constitutional Court of Thailand 2555 [2012]:5).

In addition, the Constitutional Court also framed their comment by noting that the purpose of Article 112 is to 'control the behaviour of individuals in society, ensure safety, and safeguard public peace for members of society, including strengthening the security in society' (Constitutional Court of Thailand 2555 [2012]:7). The reason why it is appropriate to do so is because speech deemed to insult, defame, or threaten the king, queen, heir apparent, or regent 'may be an action that destroys the hearts of Thai people, who have respect and love for, and are loyal to, the king and the institution of the monarchy, and may cause resentment among the people' (Constitutional Court of Thailand 2555 [2012]:6). There is no space for diversity of thought or critical perspectives on the monarchy within the polity in this formulation. If one does not love the king, it follows, then one is perhaps not Thai. Here, like the commentators on the Phuchatkan website, the Constitutional Court has taken up the role of determining who is and who is not a member of the polity.

After this introduction, which foreshadowed the Constitutional Court's dismissal of the two petitions at hand, and any future petitions, the court turned to specifically address Article 112 of the Criminal Code in relation to Sections 3 $(2), 29$, and $45(1,2)$ of the constitution.

Section 3 (2) of the constitution aims to establish the rule of law as a basis for state administration and states that ' $[\mathrm{t}]$ he National Assembly, the Council of Ministers, the Courts, other Constitutional organizations and State agencies shall perform duties of office by the rule of law'. The petition submitted by Somyot and Ekachai noted that the classification of Article 112 of the Criminal Code as a crime of national security, and the corresponding harsh punishment, was not in line with the rule of law. In response, the Constitutional Court noted that Thailand is a democratic regime with the king as head of state. The court further argued that the monarchy occupies a special position, and therefore a special law is just because the monarchy is a primary pillar of the nation, as a result of history, royal tradition, and legal convention (Constitutional Court of Thailand 2555 [2012]:5). Here, instead of considering the question of national security, and how an alleged violation of Article 112 of the Criminal Code might affect it, the court directly avoided it. The Constitutional Court instead redefined the rule of law for the Thai context to include special protection for particular individuals within the polity, namely the king, queen, heir apparent, 
and regent. Politicians and state security actors who wish to deny citizens certain liberties and freedoms sometimes refer to 'Thai-style' democracy as more appropriate to the Thai context than other forms. While vague and ill-defined, 'Thai-style' democracy always arises as a response to demands for increased rights and participation by citizens. Perhaps the Constitutional Court's idea of the rule of law might be called 'Thai-style' rule of law. Rather than a preference for law and order or rule by law in lieu of the rule of law, described by Cheesman (2014), this is instead a selective use of rule of law, or a suspension of the rule of law in special cases.

The Constitutional Court then examined Sections 29 and $45(1,2)$ together. Section 29 addresses rights, liberties, and human dignity in a broad sense. The section states that

(1) The restriction of such rights and liberties as recognized by the constitution shall not be imposed on a person except by virtue of provisions of the law specifically enacted for the purpose determined by this constitution and only to the extent of necessity and provided that it shall not affect the essential substance of such rights and liberties. (2) The law under paragraph one shall be of general application and shall not be intended to apply to any particular case or person provided that the provision of the constitution authorizing its enactment shall also be mentioned therein. (3) The provisions of paragraph one and paragraph two shall apply mutatis mutandis to rules or regulations issued by virtue of the provisions of the law.

Section 45 then addresses freedom of expression specifically and states

(1) A person shall enjoy the liberty to express his or her opinion, make speeches, write, print, publicize, and express him or herself by other means. (2) The restriction on liberty under paragraph one shall not be imposed except by virtue of the provisions of law specifically enacted for the purpose of maintaining the security of the state, safeguarding the rights, liberties, dignity, reputation, family or privacy rights of other persons, maintaining public order or good morals of preventing the deterioration of the mind or health of the public.

In response to the petition, the Constitutional Court dismissed the concern about these sections and argued that Article 112 of the Criminal Code does not have any effects on freedom of expression. The court further noted that freedom of expression must be in line with the constitution, and speech which 
defames, insults, or threatens the king, queen, heir apparent or regent is not, and therefore Article 112 of the Criminal Code does not limit freedom of expression (Constitutional Court of Thailand 2555 [2012]:7). The sheer fact that the Constitutional Court is examining this petition because two men are behind bars for words others wrote and they circulated, is an illustration of how Article 112 constricts freedom of expression. The broader fear of speaking against, or even querying, the monarchy is more difficult to quantify, yet the law is never far from the minds of all who write and publish in Thailand.

Since the Constitutional Court dismissed the petitions submitted by Somyot and Ekachai, the case against Somyot continued in the Criminal Court. A month after the Constitutional Court decision was read, the Criminal Court handed down its decision. On 23January 2013 the Criminal Court found Somyot guilty of two counts of violating Article 112. The prosecution argued that even though he was not the author of the two articles in question, his work in editing, printing, distributing, and disseminating the two issues of Voice of Taksin magazine in which Jit Phonlachan's articles, which were deemed by the prosecutor and the judges to violate Article 112, was an equal violation to authoring the two articles. For the prosecution and convicting judges in this case, as in other lèse majesté cases, the decision turned on the issue of intention. In the abbreviated decision released on the day that the judgement was issued, the court made this argument:

The two Khom Khwam Khit articles in Voice of Taksin did not refer to the names of individuals in the content. But they were written with an intention to link incidents in the past. When these incidents in the past are linked, it is possible to identify that (the unnamed individual) refers to King Bhumibol Adulyadej. The content of the articles is insulting, defamatory, and threatening to the king. Publishing, distributing, and disseminating the articles is therefore with the intention to insult, defame, and threaten the king.

Criminal Court 2556 [2013]

The decision was a clear and ominous warning to anyone involved in publishing, and as the Asian Human Rights Commission noted:

There is not an official censorship board in Thailand that officially inspects every piece of print material before it is published, but with this case, Article 112 is established as an unofficial censorship measure. What makes this particularly dangerous is that the enforcement and interpretation of Article 112 is both uneven and as indicated by this and other 
cases, highly political. Writers and publishers will not know that they have crossed the invisible line demarcated by the law until the police knock on their doors to take them away. ${ }^{14}$

Somyot is not the first person to be charged and prosecuted under Article 112 for something he did not write. In addition to Ekachai Hongkangwan noted above, who was convicted and served two years and eight months in prison for the CDS he sold, Chiranuch Premchaiporn, the executive director of the independent media site Prachatai and former webmaster of the site's now defunct webboard, was charged and prosecuted for ten counts of alleged violation of the 2007 Computer Crimes Act, with a link to Article 112, on the basis of ten comments that other people had posted to the webboard which the prosecutor alleged contained anti-monarchy content. The argument of the judges in the Criminal Court in 2012, in a decision upheld by both the Appeal Court in 2013 and the Supreme Court in 2015, was that she was guilty of one of the ten counts. In that instance, she had removed the comment after twenty days had passed. The comment being available for this length of time was judged to be a crime equal to the crime of lèse majesté that was committed by those who had posted the comments on the webboard. Chiranuch was sentenced to eight months in prison, but the sentence was suspended. Somyot, Ekachai, and Chiranuch are unlikely to be the last to be prosecuted in relation to material deemed to constitute lèse majesté that they did not author.

What makes the Constitutional Court's action particularly concerning is that it is legally binding and stands as the interpretation of the highest covenant outlining the relationship between the ruler and the ruled in Thailand. This is not the first time that the court has commented on a case related to Article 112 in a fashion that raises serious questions about their role and the current place of the constitution in the Thai polity. Daranee Charnchoengsilpakul, who is currently serving a fifteen-year sentence under Article 112 for fifty minutes of speech alleged to defame the king, was tried in secret in 2009. In 2011, in a delayed response to a petition filed by Daranee, the Constitutional Court ruled that a closed trial does not impact the rights and liberties of a citizen because the accused and the accused's lawyer are allowed to be present (Constitutional Court of Thailand 2554 [2011]). One reading is that the definition of rights and liberties advanced through this ruling is an expedient one made by a

\footnotetext{
14 Asian Human Rights Commission, 'THAILAND: Verdict in case of human rights defender is a serious threat to freedom of expression', 23-1-2013, http://www.humanrights.asia/news/ ahrc-news/AHRC-STM-027-2013 (accessed 20-1-2016).
} 
court willing to bend principles to fit its desired end. But my assessment is that there is a more pernicious process at work. Within the hyper-royalist parapolitical regime, those deemed to be disloyal to the monarchy do not register as members of the polity or as human beings. Therefore, their rights and liberties do not register as in need of protection.

\section{A Hyper-Royalist Parapolitical Coup and Regime}

The blurring of the lines between the state and para-state and the law and extrajudicial violence, which constitutes hyper-royalist parapolitics, produces a range of actions that make some citizens vulnerable to human-rights violations in the service of the glorification of the monarch. The immediate result of this has been concrete harm to the lives of these individuals, including Worachet Pakeerut and Somyot Prueksakasemsuk addressed above. Worachet Pakeerut was assaulted and all members of the Khana Nitirat faced a series of threats because their critics disagreed with their questioning of how rule is accomplished and cast it as dangerous to the monarchy and polity. Somyot Prueksakasemsuk (and others imprisoned under Article 112) has been forced to sacrifice his liberty and freedom because a panel of judges determined that his role in disseminating two articles deemed to insult the monarchy was a threat to the nation equal to that of writing the articles. By considering these two instances together-one in which extrajudicial violence is carried out by private citizens and one in which judges issue court decisions which greatly restrict rights and liberties - I have aimed to demonstrate how hyper-royalism has infiltrated both vigilante and official state action.

These two instances of hyper-royalist parapolitics took place in 2012 during the later inter-coup years after the April-May 2010 crackdown on red-shirt protestors and before the 22 May 2014 coup. This was a period in which both progressive, critical activism, such as the proposal to amend Article 112 by the Khana Nitirat and the Campaign Committee for the Amendment of Article 112, was possible and hyper-royalism was on the rise. In light of the 22 May 2014 coup and the repression that has followed, the growing hyper-royalism of the inter-coup years was a signal of what was to come.

Without access to the inner walls of the Ministry of Defence, palace, and other places where military, royal, capital, and other elites in Thailand can be found, the reasons for the 22 May 2014 coup can only be partially parsed from the public actions of the junta. With this caveat in mind, I want to conclude by proposing that the coup be viewed as one in the service of hyper-royalist parapolitics, and I offer two examples in support of this idea. 
First, there has been a sharp increase in the number of lèse majesté cases in the court system since the coup, with at least 62 new cases documented by the Internet Dialogue on Law Reform (iLaw), a Thai human-rights, nongovernmental organization, between the coup and the end of 2015. These cases are being adjudicated across the civil, criminal, and military courts; the NCPO has ordered that violations of Article 112 that take place subsequent to the coup be processed in the military court system, in which there are fewer rights protections provided to defendants. Not only has there been an increase in the total number of cases being adjudicated, but the way in which the law and its penalties are being interpreted is undergoing an expansion as well. Sentences have grown much longer, and a new record was set in August 2015, when Pongsak Sriboonpen was sentenced in the military court system to 60 years for making six Facebook posts deemed to insult the monarchy; his sentence was reduced to 30 years as he confessed and cooperated with the court. ${ }^{15}$ In December 2015, Thanakorn Siripaiboon was formally charged with violation of Article 112 for allegedly making a Facebook post insulting Tong Daeng, the king's pet dog, and is currently being held without bail while he awaits trial. ${ }^{16}$ Perhaps the judges will dismiss the charge and note that the dog is not covered by Article 112, but given that the charges have been accepted by the court, this seems unlikely. Here, to return to Thongchai Winichakul's idea of hyperroyalism, it is not only that the king and the (human) royal court have been elevated to be higher than other human beings, but the animal companions of the king have been elevated as well. It is tempting to dismiss as farce the idea that the protection of the institution of the monarchy and national security in Thailand now extends to the protection of the reputation of a pet dog, but the presence of a man behind bars for possibly impugning this reputation makes this a farce with grave consequences. If this kind of hyper-royalism continues to hold sway within Thailand, who will be left outside of prison and what shape will the polity take?

Second, in addition to the reshaping of the polity by literally removing critical voices through prosecutions and prison sentences, as well as the chilling effect these prosecutions have on society as a whole, the NCPO has also acted consistently to limit the kinds of public discussions that can take place by requiring the organizers of all public seminars to ask for permission to hold them. The Khana Nitirat has not been able to hold seminars since the coup,

\footnotetext{
15 See Case \#650, iLaw Freedom of Information Documentation Center, http://freedom.ilaw .or.th/en/case/650 (accessed 27-1-2016).

16 See Case \#702, iLaw Freedom of Information Documentation Center, http://freedom.ilaw .or.th/en/case/702 (accessed 27-1-2016).
} 
and two of its members, Professor Worachet Pakeerut and Professor Sawatree Suksri, were among those summoned by the junta for questioning, arbitrary detention, and 'attitude adjustment', immediately following the coup. ${ }^{17}$ Even if they had not been individually targeted, the NCPO's policy of public events means that seminars by the Khana Nitirat would likely be limited. If organizers do not ask for permission, the authorities may come and forcibly shut down a public event by blocking the buildings or cutting the power if the event is already in progress. Even events for which permission has been secured are subject to surveillance and possible termination if the discussion becomes too sensitive. According to iLaw, between the coup on 22 May 2014 and the end of 2015, 104 events were cancelled by the authorities, with topics including politics under the NCPO, community rights, law-making and constitution-drafting, and many others. ${ }^{18}$ Public seminars about Article 112 and the institution of the monarchy have nearly completely disappeared. Limiting and foreclosing public discussion on topics of rule in particular is another way in which the polity and the citizens within it are reshaped under a hyper-royalist parapolitical regime.

What dissident citizens were attempting to change during the inter-coup years was the relationship between the ruler and the ruled in Thailand. In reaction, conservative, hyper-royalist citizens and state entities attempted to stop this transformation. The use of threats and repression-both within and outside the law-exposed their growing panic and the building crisis behind it. Prior to the 22 May 2014 coup, it seemed as though one option was that this crisis might become too much for the hyper-royalists to sustain and they would be forced to cede sovereignty to the people. But after the coup, and the expansion of hyper-royalist parapolitical repression, this seems unlikely. The small action that scholars and other critics can take is to find the 'off-centred locations of analysis' suggested by Christopher Krupa and David Nugent, and pay attention to the experiences and voices that expose and denaturalize hyper-royalist parapolitical repression.

17 'Nitirat member Worachet Pakeerut detained by the military', Prachatai, 17-6-2014, http:// www.prachatai.org/english/node/4131 (accessed 31-1-2016).

18 iLaw, 'Review of the situation in 2015: Justice made to order, freedom still out of stock', 2312-2015, http://freedom.ilaw.or.th/en/report/review-situations-2015-justice-made -order-freedom-still-out-stock (accessed 31-1-2016). 


\section{References}

Arendt, Hannah (1951). The origins of totalitarianism. New York: Harcourt Brace.

Cheesman, Nick (2014). 'Law and order as asymmetrical opposite to rule of law', Hague Journal on the Rule of Law 6-1:96-114.

Connors, Michael K. and Kevin Hewison (2008) (eds). "Thailand's "good coup": The fall of Thaksin, the military and democracy', Journal of Contemporary Asia 38-1:1-219.

Constitutional Court of Thailand (2554 [2011]). 'Khamwinitchai san ratthathammanun, khamwinitchai thi 30/2554, ruang phicharana 8/2554'. [Constitutional Court ruling.]

Constitutional Court of Thailand (2555 [2012]). 'Khamwinitchai san ratthathammanun, khamwinitchai thi $28-29 / 2555$, ruang phicharana $16 / 2555$ and $44 / 2555$ '. [Constitutional Court ruling.]

Cribb, Robert (2009). 'Introduction: Parapolitics, shadow governance and criminal sovereignty', in: Eric Wilson (ed.), Government of the shadows: Parapolitics and criminal sovereignty, pp. 1-9. London: Pluto Press.

Criminal Court of Thailand (2556 [2013]). 'Khamphiphaksa yo, khadi dam thi $2965 /$ 2554'. [Abbreviated decision.]

Dressel, Björn (2010). 'Judicialization of politics or politicization of the judiciary? Considerations from recent events in Thailand', The Pacific Review 23-5:671-91.

Dressel, Björn (2012) (ed.). The judicialization of politics in Asia. London: Routledge.

Gray, Christine (1986). Thailand: the soteriological state in the 1970s [PhD thesis, University of Chicago.]

Harding, Andrew and Peter Leyland (2011). The constitutional system of Thailand: A contextual analysis. Oxford: Hart.

Ivarsson, Søren and Lotte Isager (2010) (eds). Saying the unsayable: Monarchy and democracy in Thailand. Copenhagen: NIAs Press.

Krupa, Christopher and David Nugent (2015). 'Off-centered states: Rethinking state theory through an Andean lens', in: Christopher Krupa and David Nugent (eds), State theory and Andean politics: New approaches to the study of rule, pp. 1-34. Philadelphia: University of Pennsylvania Press.

Marshall, Andrew MacGregor (2014). A kingdom in crisis: Thailand's struggle for democracy in the twenty-first century. London: Zed Books.

McCargo, Duncan (2005). 'Network monarchy and legitimacy crises in Thailand', The Pacific Review 18-4:499-519.

McCargo, Duncan and Peeradej Tanruangporn (2015). 'Branding dissent: Nitirat, Thailand's enlightened jurists', Journal of Contemporary Asia 45-3:419-42.

Montesano, Michael, Aekapol Chongvilaivan and Pavin Chachavalpongpun (2012) (eds). Bangkok, May 2010: Perspectives on a divided Thailand. Singapore: Institute for Southeast Asian Studies.

Munger, Frank (2011). 'Cause lawyers and other signs of progress-Three Thai narra- 
tives', in: S. Cummings (ed.), The paradox of professionalism: Lawyers and the possibility of justice, pp. 243-73. Cambridge: Cambridge University Press.

Munger, Frank (2012) 'Constructing law from development: Cause lawyers, generational narratives, and the rule of law in Thailand', in:J. Gillespie and P. Nicholson (eds), Law and development and the global discourses of legal transfers, pp. 237-76. Cambridge: Cambridge University Press.

People's Information Centre (2555 [2012]). Khwam ching phua khwamyutthitham: Hetkan lae phonkrathop chak kan salai chumnum mesa prispha 53. Bangkok: People's Information Centre.

Pratten, David and Atreyee Sen (2008). 'Global vigilantes: Perspectives on justice and violence', in: D. Pratten and A. Sen (eds), Global vigilantes, pp. 1-24. New York: Columbia University Press.

Reynolds, Craig (2012). 'Part 1: Concept', in: Craig Reynolds (ed.), 'Time's arrow and the burden of the past: A primer on the Thai un-state', Sensate: a journal for experiments in critical media practice. http://www.sensatejournal.com/2012/05/craig-reynolds-et -al-times-arrow/ (accessed 21-1-2016).

Sopranzetti, Claudio (2013). The owners of the map: Motorcycle taxi drivers, mobility, and politics in Bangkok. [PhD thesis, Harvard University.]

Streckfuss, David (2011). Truth on trial in Thailand: Defamation, treason, and lèsemajesté. London: Routledge.

Tausig, Benjamin (2013). Bangkok is ringing. [PhD thesis, New York University.]

Thak Chaloemtiarana (1979). Thailand: The politics of despotic paternalism. Bangkok: Social Science Association of Thailand.

Thanapol Eawsakul (2550 [2007]) (ed.) Rathaprahan 19 kanya: Rathaprahan phua rabob prachathipatai an mi phramahakasat pen pramuk. Bangkok: Fa Diew Kan.

Thongchai Winichakul (2555 [2012]). 'Rabob sangkhom kanmuang thi khad fun kanplianplaeng khu antaray thi thae ching. [Lecture in support of the proposed amendment of Article 112, Friends of the Constitution, Bangkok, 11 February.]

Ünaldi, Serhat (2016). Working towards the monarchy: The politics of space in downtown bangkok. Honolulu: University of Hawai'i Press.

Wilson, Eric (2009). 'Deconstructing the shadows', in: Eric Wilson (ed.), Government of the shadows: Parapolitics and criminal sovereignty, pp. 13-55. London: Pluto Press. 